\title{
Cell cycle and physiological characteristics of Synechococcus (WH7803) in chemostat culture
}

\author{
Hongbin Liu ${ }^{1, *}$, Robert R. Bidigare ${ }^{1}$, Edward Laws $^{1}$, Michael R. Landry ${ }^{1}$, \\ Lisa Campbell ${ }^{2}$
}

\author{
${ }^{1}$ Department of Oceanography, University of Hawaii at Manoa, 1000 Pope Road, Honolulu, Hawaii 96822, USA \\ ${ }^{2}$ Department of Oceanography, Texas A\&M University, College Station, Texas 77843-3146, USA
}

\begin{abstract}
The marine cyanobacterium Synechococcus spp. is one of the most abundant picoplanktonic photoautotrophs in the world's oceans. When grown in nitrogen-limited chemostat culture under continuous light, Synechococcus strain WH7803 displays a bimodal DNA histogram. Consequently, the duration of each growth phase can be computed from the proportion of cells in each cell cycle phase. We measured cellular DNA distribution, carbon and nitrogen content, and pigment composition of Synechococcus WH7803 in a series of chemostat experiments with growth rate ranging from 0.1 to $0.9 \mathrm{~d}^{-1}$. Flow cytometric data showed that the duration of each cell cycle phase increased linearly with doubling time, and the fraction of cells in the $S$ and $G_{2}$ phases, $f_{S+G 2}$, was relatively constant at growth rates of less than 1 doubling $\mathrm{d}^{-1}$. Cellular carbon and nitrogen contents were about $200 \mathrm{and} 40 \mathrm{fg} \mathrm{cell}^{-1}$, respectively, but were much higher for slowly growing cells. The carbon to nitrogen ratio, the carbon to chlorophyll a ratio, and the ratio of zeaxanthin to chlorophyll a all decreased with increasing growth rate. These observed relationships are useful for applying cell cycle analysis to estimate growth rate, or for using cell abundance or pigment concentrations to estimate biomass and productivity of Synechococcus in the sea.
\end{abstract}

KEY WORDS: Synechococcus $\cdot$ Cell cycle $\cdot \mathrm{C}: \mathrm{N}$ ratio $\cdot$ Pigments $\cdot$ Chemostat

\section{INTRODUCTION}

Prokaryotic coccoid cyanobacteria are among the most important components of the picoplankton $(0.2$ to $2 \mu \mathrm{m}$ ) in both marine and freshwater ecosystems (see review by Weisse 1993, Partensky et al. 1999). In tropical and subtropical oceanic waters, phycoerythrin-rich (PE) cyanobacteria of the Synechococcus type (Johnson \& Sieburth 1979, Waterbury et al. 1979) and the prochlorophyte Prochlorococcus marinus (Chisholm et al. 1988, 1992) are the 2 dominant groups, and their relative importance varies among oceanic regions.

Growth rate estimates based on cell cycle descriptors, such as frequency of dividing cells (McDuff \& Chisholm 1982) and DNA frequency distributions (Carpenter \& Chang 1988), must rely on knowledge of

- Present address: Institute of Hydrospheric-Atmospheric Sciences, Nagoya University, Chikusa-ku, Nagoya 464-8601,

Japan. E-mail: hliu@ihas.nagoya-u.ac.jp the cell cycle characteristics of relevant organisms. Vaulot et al. (1996) reported that the Synechococcus cell cycle in natural populations from the Mediterranean Sea in summer was synchronized to the lightdark cycle, a pattern similar to the cell cycle of Prochlorococcus. However, flow cytometric analysis of DNA frequency distributions of different laboratory strains of Synechococcus has revealed 2 different 'modes' of cell cycle regulation (Armbrust et al. 1989, Binder \& Chisholm 1990, 1995). The first mode is consistent with the slow-growth paradigm of the prokaryotic cell cycle; all distributions were bimodal, with peaks corresponding to 1 and 2 genome equivalents The second mode appears to involve asynchronous initiation of chromosome replication, the presence of multiple chromosome copies at low growth rates, and variability in chromosome copy number among cells in the population. For strains possessing the later mode of DNA replication, the Carpenter \& Chang (1988) model cannot be applied to growth rate estimation because 
no information regarding cell division can be obtained from their cellular DNA distributions. In other words, the dividing cells can have all possible amounts of DNA. Analyses of field samples from the Arabian Sea have confirmed the co-existence of these 2 cell cycle patterns (Liu et al. 1998). Moreover, the population possessing a bimodal cell cycle sometimes has 2 not completely separated peaks of cells in the $\mathrm{S}$ and $\mathrm{G}_{2}$ phases; one occurs right after sunrise and the other around sunset. This dual-peak distribution makes the estimation of the duration of the $S$ and $G_{2}$ phases, $t_{S+G 2 \text { r }}$ from diel sampling impossible, because it is not clear whether cells dividing in the second peak are S-phase cells of the first peak that have not completed their division or cells that just entered their $S$ phase after the first peak.

Carbon conversion factors also introduce variability into interpretations of microbial dynamics. Errors can be introduced when cell abundances are converted to biomass or growth rates to carbon production. Previous estimates of cellular carbon content were obtained either from laboratory batch cultures (Waterbury et al. 1986, Kana \& Glibert 1987, Verity et al. 1992), or indirectly from the measurement of other cellular properties (Takahashi et al. 1985, Veldhuis et al. 1997). Most of these experiments were performed under nutrient-replete conditions, whereas phycoerythrinrich oceanic Synechococcus spp, are most abundant in nutrient-deplete oligotrophic regions (Glover et al. 1985, Burkill et al. 1993).

Continuous culture is designed to achieve a steadystate condition amenable to simple kinetic analysis of growth. This makes it possible to elucidate ecological principles and physiological mechanisms of organisms as related to natural conditions (Rhee 1980). In a nutrient-limited system, the growth rate of phytoplankton at steady-state must equal the growth chamber dilution rate, which equals the overflow rate divided by the volume of the growth chamber (Laws \& Bannister 1980). Here we report characteristics of the physiology and cell cycle of Synechococcus spp. grown in a series of nutrient-limited chemostat experiments. The primary purpose of this study was to determine whether the duration of cell division was constant at different growth rates. Variations in physiological properties of Synechococcus spp. such as cellular carbon, nitrogen and pigment contents, were also determined for different growth rates.

\section{MATERIALS AND METHODS}

Chemostat continuous culture system. Synechococcus strain WH7803 was grown in $\mathrm{f} / 2$ medium in a continuous culture system under nitrate-limited condi- tions. Modifications from previously described chemostats (Laws \& Caperon 1976, Laws et al. 1995) included 1 I polycarbonate growth chamber and Teflon tubing for all connections. The growth chamber, connection tubing and medium supply container were acidcleaned and autoclaved before each experiment. Medium was made from $0.2 \mu \mathrm{m}$ filtered surface seawater from Station ALOHA with a nitrate concentration

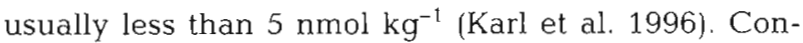
centrations of nitrate and phosphate were measured in the inflow and outflow for each experiment using a Technicon Autoanalyzer II continuous flow system.

Ten experiments were conducted under continuous white fluorescent light $\left(100 \mu \mathrm{Ein}^{-2} \mathrm{~s}^{-1}\right)$ with growth rate ranging from 0.1 to $0.9 \mathrm{~d}^{-1}$ (Table 1). Average light intensity in the growth chamber was estimated from chlorophyll a concentration, the diameter of the growth chamber and an assumed extinction coefficient of $17 \mathrm{~m}^{2} \mathrm{mg}^{-1} \mathrm{chl}$ a using an equation adapted from Bannister (1974). Average light intensity in the growth chamber calculated by this method ranged from 96 to $99 \%$ of the incident light intensity for each experiment. Cultures were grown at room temperature $\left(-23^{\circ} \mathrm{C}\right)$, and desired growth rates were achieved by adjusting the overflow rate to a proportion of the volume of the growth chamber. Synechococcus cells were monitored by withdrawing $1 \mathrm{ml}$ subsamples daily and counting by flow cytometry. Flow cytometric DNA analysis (see below) conducted for a set of samples taken every $2 \mathrm{~h}$ over a $24 \mathrm{~h}$ period during 1 experiment confirmed that Synechococcus division remained asynchronous at chemostat steady-state. When the biomass in the chemostat reached steady-state, cells were harvested for particulate organic carbon and nitrogen measurements, pigment determinations, flow cytometric analyses, and bulk and compound-specific stable carbon

Table 1. Dilution (growth) rates of Synechococcus strain WH7803 and nutrient concentrations for the chemostat experiments

\begin{tabular}{|c|c|c|c|c|c|}
\hline \multirow{3}{*}{$\begin{array}{l}\text { Growth } \\
\text { rate } \\
\left(\mathrm{d}^{-1}\right)\end{array}$} & \multirow{3}{*}{$\begin{array}{l}\text { Duration of } \\
\text { experiment } \\
\text { (d) }\end{array}$} & \multicolumn{4}{|c|}{$\begin{array}{l}\text { Nutrient concentrations in media } \\
\text { (uM) }\end{array}$} \\
\hline & & \multicolumn{2}{|c|}{ InfIow } & \multicolumn{2}{|c|}{ Outflow } \\
\hline & & $\mathrm{PO}_{4}^{-3}$ & $\mathrm{NO}_{3}{ }^{-\mathrm{d}}$ & $\mathrm{PO}_{4}^{-3}$ & $\mathrm{NO}_{3}^{-3}$ \\
\hline 0.1 & 18 & 27.2 & 98.3 & 19.6 & $<0.03$ \\
\hline 0.1 & 19 & 272 & 98.3 & 16.4 & $<0.03$ \\
\hline 0.2 & 8 & 28.9 & 98.3 & 17.9 & $<0.03$ \\
\hline 0.2 & 9 & 28.9 & 98.3 & 20.6 & $<0.03$ \\
\hline 0.4 & 30 & 22.4 & 1.09 .9 & 15.7 & 0.0 \\
\hline 0.5 & 39 & 26.8 & 108.0 & 18.8 & $<0.03$ \\
\hline 0.6 & 30 & 24.7 & 112.8 & 16.8 & 0.0 \\
\hline 0.7 & 42 & 28.9 & 104.1 & 20.1 & $<0.03$ \\
\hline 0.7 & 23 & 27.2 & 98.3 & 19.4 & 0.0 \\
\hline 0.9 & 50 & 32.0 & 94.5 & 29.1 & 46.0 \\
\hline 'Include & $\mathrm{NO}_{2}^{-}$ & & & & \\
\hline
\end{tabular}


isotope analyses (Laws et al. 1995, 1997). Plastic gloves were worn, and sterilized labware was used during subsampling to minimize contamination.

Particulate carbon, nitrogen and pigment analyses. Triplicate $50 \mathrm{ml}$ subsamples of culture from the growth chamber were filtered onto precombusted GF/F filters for particulate organic carbon (POC) and nitrogen (PON) determinations using a Perkin-Elmer model 2400 CHN elemental analyzer. Cellular carbon and nitrogen contents of Synechococcus were obtained from POC and PON concentrations divided by cell concentrations from flow cytometric analyses. Since the cultures were not axenic, cellular carbon and nitrogen contents for Synechococcus were corrected by subtracting the bacterial carbon and nitrogen, which was calculated assuming $20 \mathrm{fg} \mathrm{C}$ and $5.6 \mathrm{fg} \mathrm{N}$ per heterotrophic bacterium (Lee \& Fuhrman 1987). Only in 2 experiments, under very low dilution rates $(0.1$ and $0.2 \mathrm{~d}^{-1}$ ), were the bacterial cell concentrations more than twice those of Synechococcus. Heterotrophic bacterial carbon estimates were never more than $10 \%$ of the total POC in any of the experiments.

For pigment analysis, $10 \mathrm{ml}$ subsamples were filtered onto GF/F filters, placed in $90 \%$ acetone, and sonified. Following extraction at $0^{\circ} \mathrm{C}$ in darkness for $>24 \mathrm{~h}$, the samples were analyzed by reverse phase-high performance liquid chromatography (RP-HPLC) following the methods described in Andersen et al. (1996). Quantification was facilitated by addition of a known quantity of internal standard (canthaxanthin) to each sample extract.

Flow cytometry. One $\mathrm{ml}$ samples were preserved with paraformaldehyde $(0.2 \%$ final concentration $)$ and analyzed using a Coulter EPICS 753 flow cytometer (Coulter Co., Hialeah, FL) equipped with two $5 \mathrm{~W}$ Argon lasers and MSDS automatic sampler (Liu et al. 1997). Samples stained with Hoechst 33342 (final concentration of $2 \mu \mathrm{g} \mathrm{ml}^{-1}$ ) were incubated at $37^{\circ} \mathrm{C}$ in the dark for $1 \mathrm{~h}$ to improve the precision of the histograms of DNA fluorescence (Liu et al. 1998). Most samples were diluted with double-filtered $(0.2 \mu \mathrm{m})$ seawater for optimal counting efficiency. Concentrations of Synechococcus and heterotrophic bacteria were counted for each sample. Fluorescence and right-angle light scatter (RALS) were collected by photomultiplier tubes. DNA (blue) fluorescence was normalized to $0.46 \mu \mathrm{m}$ UV beads, and other signals were normalized to $0.57 \mu \mathrm{m}$ Fluoresbrite YG beads (Polysciences, Warrington, PA). In addition to listmode files, 1-parameter histogram files, containing the linear blue (DNA) fluorescence data for Synechococcus populations, were collected and analyzed with MCYCLE software (Phoenix Flow Systems, San Diego, CA) to compute the fraction of cells in the $G_{1}, S$ and $G_{2}$ phases. Assuming completely asynchronous growth, the duration of each cell cycle phase $\left(t_{x}\right)$ was calculated from the fractions of the population in each phase $\left(f_{x}\right)$ and the growth rate $(\mu)$ of the culture in steady-state using the equations of Slater et al. (1977):

$$
\begin{aligned}
& t_{\mathrm{G} 1}=-\ln \left(1-f_{\mathrm{C} 1} / 2\right) / \mu \\
& t_{\mathrm{G} 2}=\ln \left(1+f_{\mathrm{G} 2}\right) / \mu \\
& t_{\mathrm{S}}=\ln \left[1+f_{\mathrm{S}} /\left(1+f_{\mathrm{G} 2}\right)\right] / \mu
\end{aligned}
$$

\section{RESULTS}

\section{Synechococcus cell cycle}

DNA distributions of Synechococcus WH7803 were consistently bimodal in continuous culture (Fig. 1). The average coefficients of variation (CV) of the $\mathrm{G}_{1}$ and $\mathrm{G}_{2}$ peaks were 10 to $14 \%$ in the samples stained with the protocol described above. The durations of each cell cycle phase increased linearly with doubling time, and the increase in the $G_{1}$ phase accounted for most of the increased cycle time (Fig. 2). The duration of the $S$ and $\mathrm{G}_{2}$ phases, $t_{\mathrm{S}+\mathrm{G} 2}$, was as long as $46 \mathrm{~h}$ when Synechococcus was growing at $0.1 \mathrm{~d}^{-1}$ and decreased to a low value of $\sim 8.1 \mathrm{~h}$ at $0.7 \mathrm{~d}^{-1}$ (Table 2). The linear relationship between doubling time (DT) and $t_{\mathrm{S}+\mathrm{G} 2}\left(t_{\mathrm{S}+\mathrm{G} 2}=\right.$ $1.93+0.28 \mathrm{DT}, \mathrm{r}=0.99$ ) implies that the cells spend 28 to $36 \%$ of their time in the $\mathrm{S}$ and $\mathrm{G}_{2}$ phases at doubling times of $1 \mathrm{~d}$ or greater. A plot of the fraction of cells in the $S$ and $G_{2}$ phases, $f_{S+G 2}$, is in fact rather constant, except when the growth rate exceeded 1 doubling $\mathrm{d}^{-1}$ $\left(\mu=0.9 \mathrm{~d}^{-1}\right.$, Fig. 3). The nitrate concentration in the growth chamber was high $(46 \mu \mathrm{M})$ only in the experiment performed at a dilution rate of $0.9 \mathrm{~d}^{-1}$, indicating in that case that light or temperature limited growth rate rather than nitrate (Table 1 ).

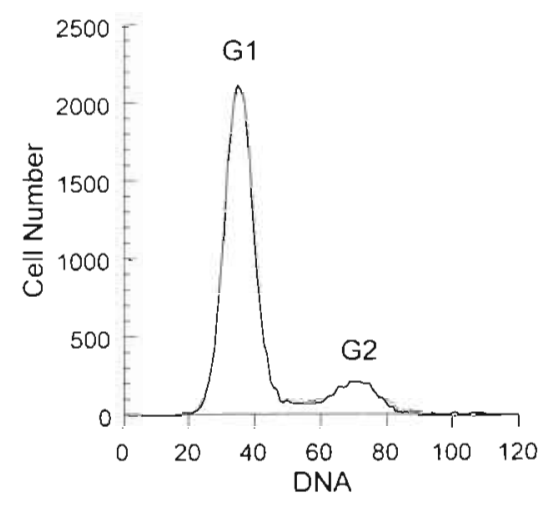

Fig. 1. Bimodal DNA fluorescence distribution observed for Synechococcus WH7803 growing at $0.7 \mathrm{~d}^{-1}$ in chemostat culture. $X$-axis: DNA fluorescence normalized to $0.46 \mu \mathrm{m}$ UV beads. $Y$-axis: relative cell density. The $\% \mathrm{CV}$ for $\mathrm{G}_{1}$ in this example was 11.7 


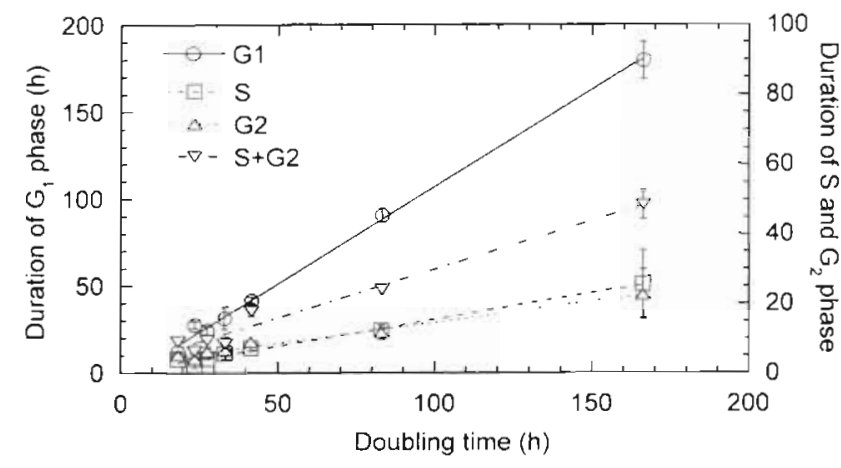

Fig. 2. Durations of cell cycle phases in Synechococcus WH7803 growing in a nitrate-limited chemostat as a function of the population doubling time. Error bars show $\pm 1 \mathrm{SD}$ of the mean

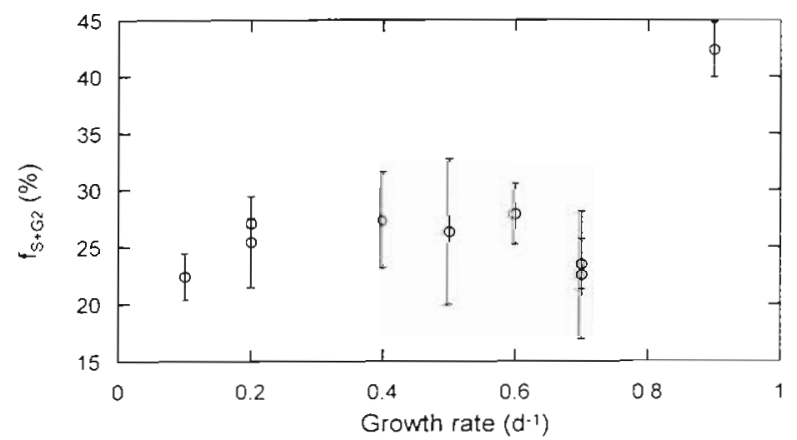

Fig. 3. Fraction of Synechococcus WH7803 cells in S and $\mathrm{G}_{2}$ phases $\left(f_{S+G_{2}}\right)$ as a function of growth rate in a nitrate-limited chemostat. Error bars show \pm 1 SD of the mean

\section{Carbon and nitrogen content}

The carbon and nitrogen cell quotas of Synechococcus WH7803 were highly variable at different growth rates. Nevertheless, both carbon and nitrogen cell quotas appeared to decrease with growth rate except at $\mu=0.9 \mathrm{~d}^{-1}$, where nitrogen did not limit growth rate (Fig. 4A,B). Cel-

Table 2. Duration of each cell cycle phase of Synechococcus WH7803 growing in nitrate-limited chemostat. Numbers in parentheses are $1 \mathrm{SD}$ of the means

\begin{tabular}{|lcrrr|}
\hline \multirow{2}{*}{$\begin{array}{c}\text { Growth } \\
\text { rate }\left(\mathrm{d}^{-1}\right)\end{array}$} & \multicolumn{5}{c}{ Duration of each cell cycle phase (h) } \\
\hline 0.1 & $\mathrm{G}_{1}$ & $\mathrm{~S}$ & \multicolumn{1}{c|}{$\mathrm{G}_{2}$} & $\mathrm{~S}+\mathrm{G}_{2}$ \\
\hline 0.2 & $180.0(10.7)$ & $25.7(9.8)$ & $22.7(7.3)$ & $48.4(4.0)$ \\
0.4 & $90.5(4.0)$ & $12.3(0.6)$ & $11.7(2.1)$ & $24.0(1.5)$ \\
0.5 & $41.6(2.0)$ & $7.1(0.8)$ & $9.0(0.0)$ & $17.8(1.5)$ \\
0.6 & $31.4(6.3)$ & $5.6(0.7)$ & $6.5(2.7)$ & $8.4(1.9)$ \\
0.7 & $24.5(2.4)$ & $4.1(0.1)$ & $6.2(1.2)$ & $9.4(0.2)$ \\
0.9 & $27.6(2.1)$ & $2.3(0.7)$ & $4.0(0.6)$ & $6.3(0.7)$ \\
& $12.1(0.3)$ & $3.9(0.2)$ & $5.1(0.4)$ & $9.0(0.2)$ \\
\hline
\end{tabular}
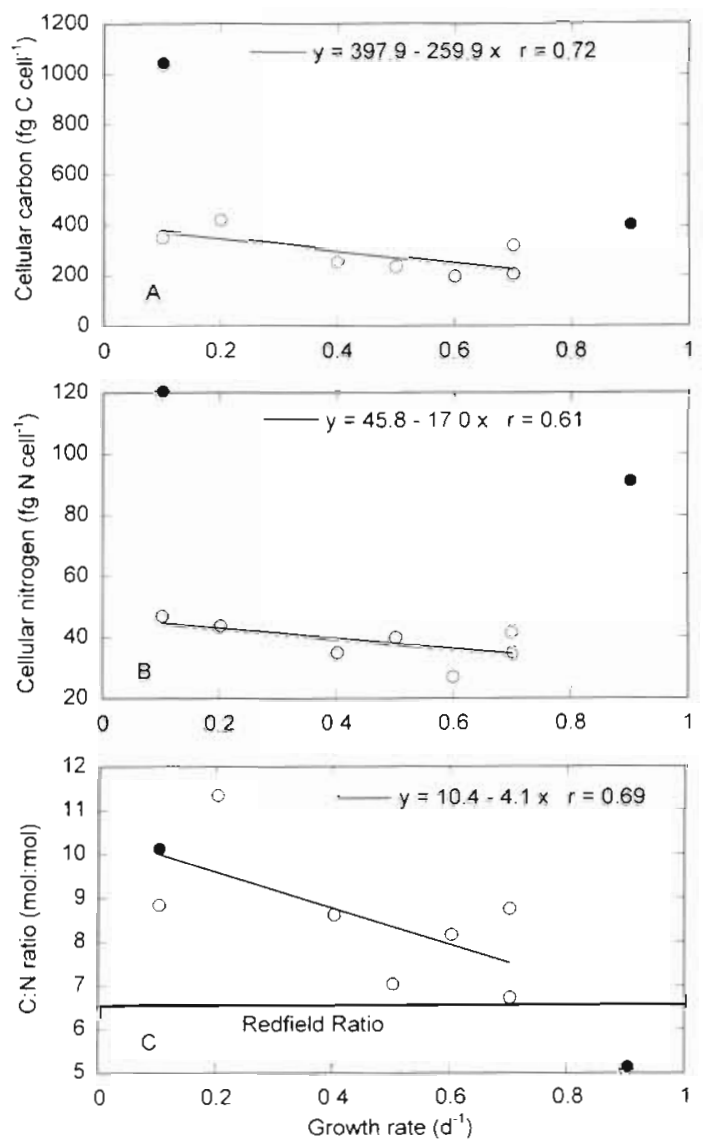

Fig. 4. Variations in the (A) cellular carbon, $(B)$ nitrogen, and (C) C:N ratio as a function of growth rate of Synechococcus strain WH7803. $(0, \bullet)$ Mean value of triplicate samples. (•) Data not included in the linear regression (see text for details)

lular carbon content decreased from about $500 \mathrm{fg} \mathrm{C} \mathrm{cell}^{-1}$ at $\mu=0.2 \mathrm{~d}^{-1}$ to around $200 \mathrm{fg} \mathrm{C} \mathrm{cell}{ }^{-1}$ at $0.7 \mathrm{~d}^{-1}$. Nitrogen per cell dropped from 60 to $40 \mathrm{fg} \mathrm{N} \mathrm{Nell}^{-1}$. The observed trends of decreasing cellular carbon and nitrogen quotas and $\mathrm{C}: \mathrm{N}$ ratios with increasing growth rate were statistically significant ( $t$-test of slope of linear regression, $p<0.05,0.1$ and 0.1 , respectively). The regression line in Fig. 4 excluded an extremely high estimate of carbon and nitrogen content determined at $\mu=0.1 \mathrm{~d}^{-1}$. We are cautious about overinterpreting this result, however, since there were 8 times more heterotrophic bacteria than Synechococcus cells in the sample taken from this experiment compared to a heterotrophic bacteria: Synechococcus ratio of less than 1 in most other experiments. The $C: N$ ratio also decreased with increasing growth rate and approached the Redfield ratio (6.7. atom:atom) at higher growth rates under nitrogen limitation (Fig. 4C). The $\mathrm{C}: \mathrm{N}$ ratio dropped to 5.1 (atom:atom) when the cultures were grown under nitrate and phosphate replete conditions. 

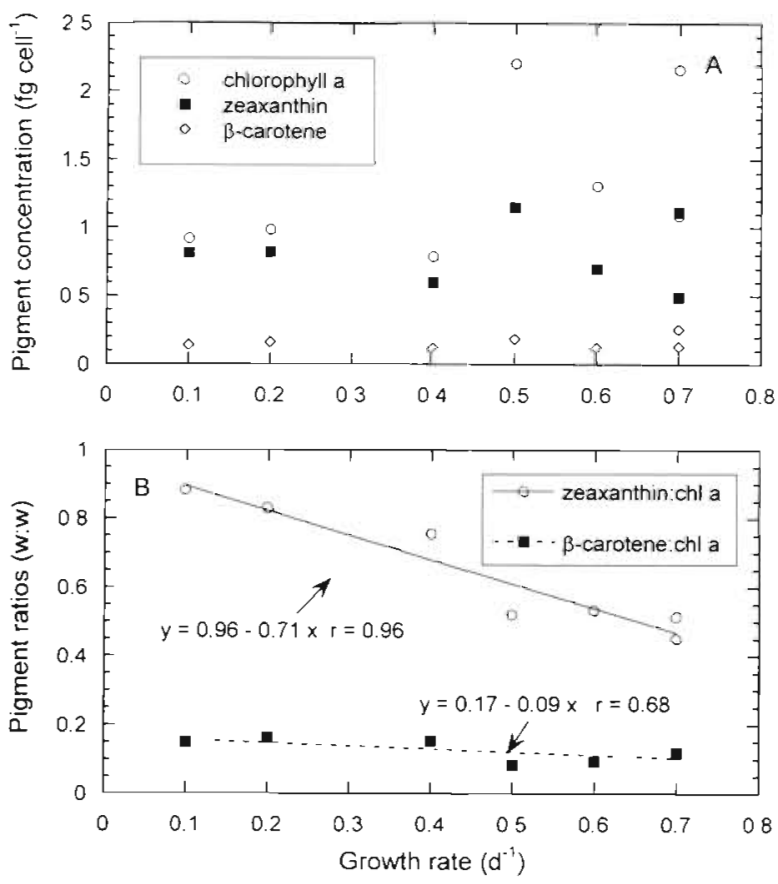

Fig. 5. Variations in the (A) cellular chlorophyll $a$, zeaxanthin and $\beta$-carotene concentrations, and (B) ratios of zeaxanthinto-chlorophyll $a$ and $\beta$-carotene-to-chlorophyll $a$ as a function of growth rate of Synechococcus strain WH7803

\section{Pigment composition}

HPLC data showed no clear relationships between cellular chlorophyll $a$, zeaxanthin, $\beta$-carotene and growth rate, although the chlorophyll a content was generally higher in the faster-growing cells (Fig. 5A). Ratios of zeaxanthin- and $\beta$-carotene-to-chlorophyll $a$ $(w: w)$ at high dilution rates were 0.50 and 0.12 , respectively, and were higher at low dilution rates (Fig. 5B). These values are in general agreement with the results of Kana et al. (1988) and Bidigare et al. (1989). The florescence data from flow cytometric analysis showed similar patterns (Fig. 6). There was a significant linear relationship $(r=0.91$ ) between the chlorophyll a cell quotas (fg cell ${ }^{-1}$ ) and cellular red fluorecence ([chl] = $-0.1265+0.1137$ [red fluorescence], geometric mean model 2 linear regression). Red and orange fluorescence, representing chlorophyll and $\mathrm{PE}$, respectively, both showed an increasing trend with growth rate (Fig. 6B,C). The ratio of red (chlorophyll) to orange (PE) fluorescence did not show a clear trend, but was higher $(-7)$ at the lowest dilution rate $\left(0.1 \mathrm{~d}^{-1}\right)$. When nitrate was not limiting growth rate, both red and orange fluorescence cell ${ }^{-1}$ were significantly higher, and the red:orange fluorescence ratio was about 5 . The carbon-to-chlorophyll a ratio (w:w) was as high as 500 by weight at $\mu=0.1 \mathrm{~d}^{-1}$ and decreased to about 150 at $\mu=0.7 \mathrm{~d}^{-1}$ (Fig. 7A).

\section{DISCUSSION}

We observed a bimodal DNA distribution for Synechococcus WH7803 when grown in our chemostat system under nitrate-limiting conditions. This observation
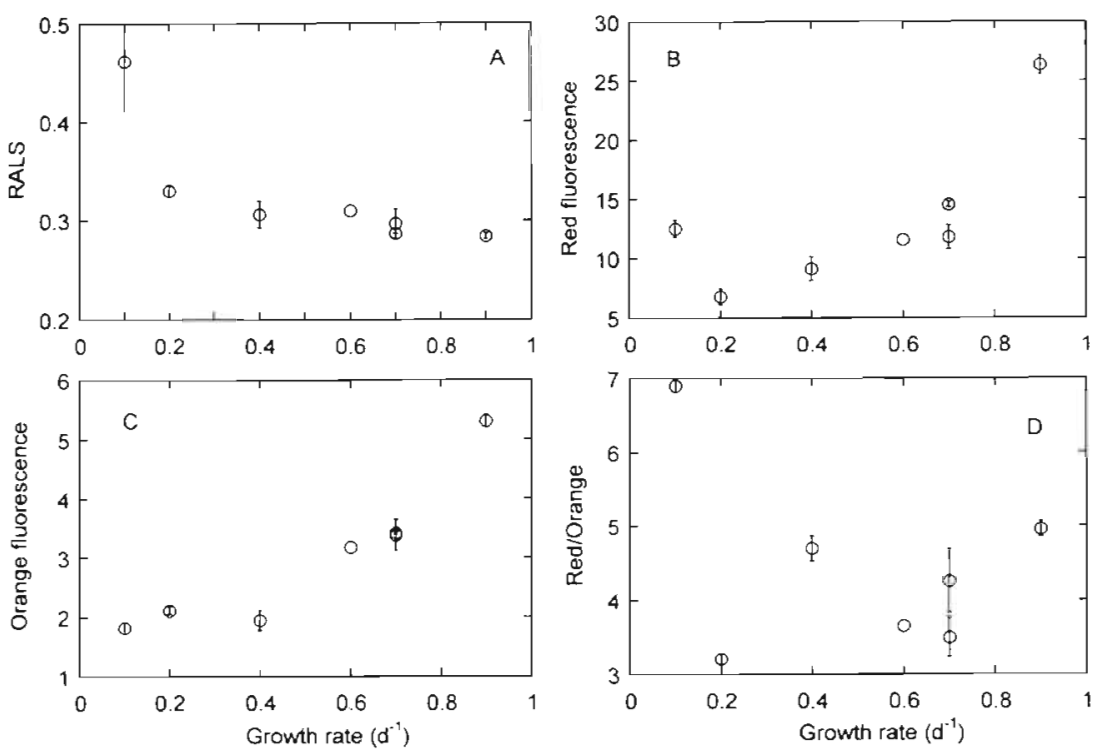

Fig. 6. Variations of right-angle light scatter (RALS) and fluorescence measured by flow cytometer (normalized to $0.57 \mu \mathrm{m}$ beads, arbitrary units) for Synechococcus WH7803 growing in chemostat cultures under continuous light. Error bars show 1 SD for triplicate samples 

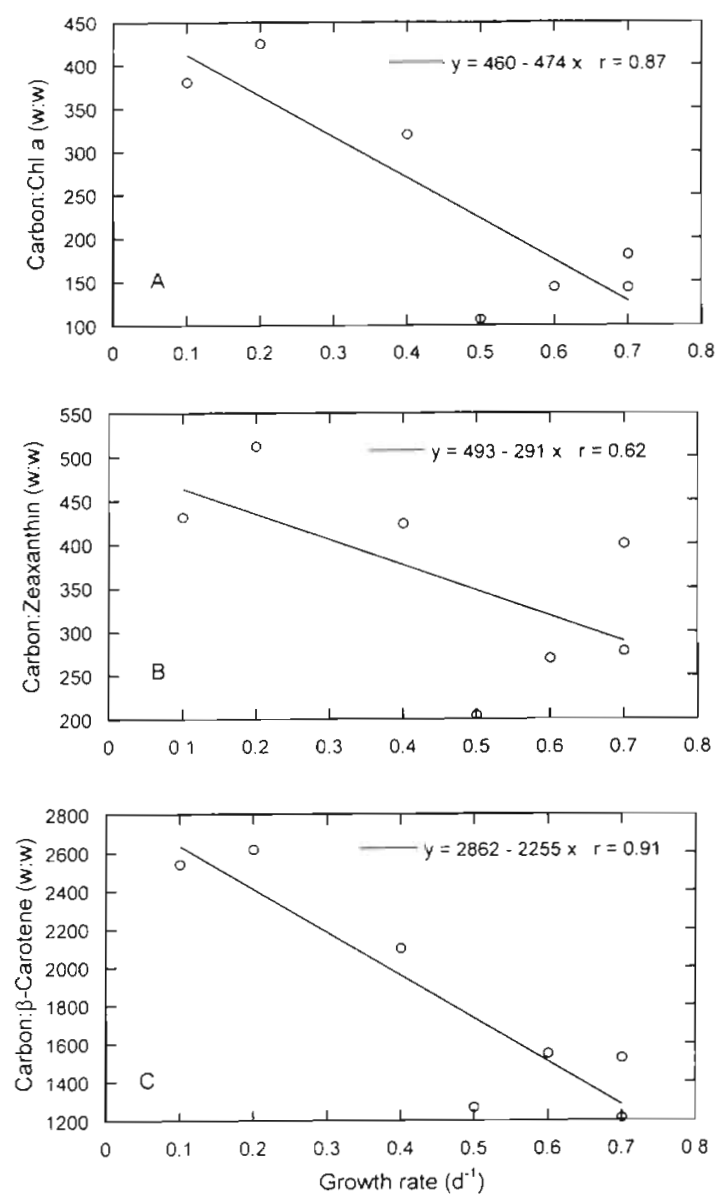

Fig. 7. Variations in ratios of (A) cellular carbon-to-chlorophyll $a_{1}$ (B) carbon-to-zeaxanthin, (C) and carbon-to- $\beta$-carotene of Synechococcus WH7803 as a function of growth rate. All trends are statistically significant ( $t$-test of slope of linear regression, $\mathrm{p}<0.01,0.1$ and 0.005 , respectively)

differs from the findings of Binder \& Chisholm (1995), who reported a multimodal DNA distribution in their slow-growing batch cultures. Binder \& Chisholm (1995) used a methanol extraction to improve the quality of staining. They also suggested that there might be a diel variation in stainability in Synechococcus WH7803 grown under a diel light-dark regime. We found that a $1 \mathrm{~h}$ incubation at $37^{\circ} \mathrm{C}$ improved the quality of staining. The software we used to deconvolute the DNA frequency distribution worked perfectly with the low 11 to $14 \% \mathrm{CVs}$ for $\mathrm{G}_{1}$ and $\mathrm{G}_{2}$ peaks in our data. Without further comparsions between different techniques, the most likely explanation for the difference in DNA distributions reported here and by Binder \& Chisholm (1995) is the difference in culture conditions, e.g. batch versus continuous cultures and light versus nitrogen limitations.

The present results from chemostat experiments demonstrate that the duration of all cell cycle phases of
Synechococcus clone WH7803 vary with growth rate. This result is different from the cell cycle characteristics observed by Chisholm et al. (1986) for Synechococcus strain WH8101. Over a range of doubling times from 14 to $55 \mathrm{~h}$ adjusted by different light intensities, they found that the $\mathrm{G}_{1}$ and $\mathrm{G}_{2}$ phases expanded with increasing generation time, but that the duration of the $\mathrm{S}$ phase was constant. They further predicted that Synechococcus should arrest in both $G_{1}$ and $G_{2}$ when placed in the dark for extended periods. They based this conclusion on the observation of $\mathrm{G}_{2}$ expansion in response to light limitation, and on the persistent doublet population observed during the dark period in populations grown on diel photocycles (Waterbury et al. 1986). However, the effect of $N$ limitation on the cell cycle of Synechococcus appears to be different from that of light limitation. All DNA cell cycle phases were lengthened, though not equally, with an increase of doubling time (Fig. 2). This response is analogous to the responses of Thalassiosira weissflogii (centric diatom) and Hymenomonas certerae (coccolithophore) to nitrogen limitation (Olson et al. 1986). Although the amount of light is critical for Synechococcus cells to start DNA synthesis and cell division as suggested by Chisholm et al. (1986), our results suggest that nitrogen limitation can further prolong the duration of DNA synthesis.

Estimating species-specific growth rates of marine phytoplankton based on cell cycle terminal events, i.e. $\mathrm{S}+\mathrm{G}_{2}$ phases, requires knowledge of terminal event duration. In highly synchronized, slow-growing species, $t_{S+G 2}$ can be calculated as twice the time difference between 2 successive peaks of the fraction of cells in the $\mathrm{S}\left(f_{\mathrm{S}}\right)$ and $\mathrm{G}_{2}\left(f_{\mathrm{G} 2}\right)$ phases (Carpenter \& Chang 1988). The Carpenter \& Chang (1988) model would still be valid for populations with growth rates exceeding 1 doubling $\mathrm{d}^{-1}$. However, it is often difficult to measure the duration of the selected terminal event for each cohort, because the maxima for each cohort partially overlap (Chisholm et al. 1984). Alternatively, a $t_{d}$ obtained from laboratory cultures over a range of growth conditions may be used for field populations under the assumption that the natural populations have the same cell cycle characteristics as laboratory cultures. Our results showed a linear relationship between the population doubling time and the duration of the $\mathrm{S}$ and $\mathrm{G}_{2}$ phases for Synechococcus grown in a N-limited chemostat (Fig. 2). Although this relationship may be applied to field populations, extreme caution must be taken, because an estimate derived in laboratory culture may not be characteristic of field populations. Cultures growing in chemostats may express abnormal physiology relative to natural populations. For example, Synechococcus strains maintained under continuous light have cell volumes about 
$30 \%$ larger than cells grown on a light-dark cycle (Waterbury et al. 1986). However, we contend that the best approach is to use the in situ DNA histograms to estimate the $t_{S+G_{2}}$ wherever possible. Even if 2 peaks of cells in the $S$ and $G_{2}$ phases are observed, it is probably more accurate to assume that the $t_{S+G 2}$ value for the dominant set of peaks can be applied to the second set than it is to apply an estimate from a laboratory culture. Interestingly, growth rate estimates that use a DNA histogram-derived $t_{\mathrm{S}+\mathrm{G} 2}$ value generally agree well with independent measures of growth rate based on cell counts (Liu et al. 1998, Shalapyonok et al. 1998), even if there is a dual-peak in the cell cycle phases. Only in a situation where it is absolutely impossible to estimate $t_{\mathrm{S}+\mathrm{G} 2}$ from field data because of asynchronous division or multiple DNA peaks, the use of laboratoryderived $t_{\mathrm{S}+\mathrm{G} 2}$ becomes the only choice.

The duration of the $\mathrm{S}$ and $\mathrm{G}_{2}$ phases observed for the Synechococcus cells growing at $0.9 \mathrm{~d}^{-1}$ was actually no shorter than that of cells growing at $\sim 1$ doubling $\mathrm{d}^{-1}$ $\left(0.5\right.$ to $0.7 \mathrm{~d}^{-1}$, Table 2$)$. This indicates that fast-growing Synechococcus follow the ultradian growth mode observed in Prochlocococcus, a close relative of Synechococcus (Liu 1997, Shalapyonok et al. 1998). Instead of shortening each cell cycle phase proportionally, the cells achieve fast growth by dramatically reducing the $\mathrm{G}_{1}$ phase of part of the population, i.e. a portion of the population undergoes a second DNA replication and cell division just after the completion of the first cycle. Meanwhile, the duration of the $S$ and $G_{2}$ phases remains relatively constant. As a consequence, the fraction of cells in the $S$ and $G_{2}$ phases is higher in the chemostat at a growth rate of more than 1 doubling $\mathrm{d}^{-1}$ than at growth rates less than 1 doubling $\mathrm{d}^{-1}$. Observations of dual peaks of $S$ and $G_{2}$ phases in near-surface waters of the Arabian Sea, with the first peak occurring in the morning and the second in the afternoon, suggest that this ultradian growth mode may be common for oceanic species of Synechococcus (Liu et al. 1998).

Our estimate of cell carbon for Synechococcus is similar to previous studies when $\mu=0.7 \mathrm{~d}^{-1}$, but higher under lower growth rates. Waterbury et al. (1986) reported that carbon per cell of the same strain ranged from 150 to $290 \mathrm{fg} \mathrm{C} \mathrm{cell}^{-1}$ during a diel cycle, with the lowest values occurring during the period of no cell division. Kana \& Glibert (1987) measured 200 to $300 \mathrm{fg}$ $C$ cell $^{-1}$ for the same strain cultured under a wide range of growth irradiances. Burkill et al. (1993) and Veldhuis et al. (1997) both estimated, using different approaches, a carbon content for Synechococcus of $175 \mathrm{fg} \mathrm{C} \mathrm{cell}^{-1}$ in near-surface waters of the northwestern Arabian Sea; cellular carbon increased with depth as cell volume increased. Unfortunately, due to instrument constraints, we did not have reliable flow cytometric forward angle light scatter (FALS) data, which is a more direct indicator of the cell size. The RALS, on the other hand, is a complex function of size and refractive index (Morel 1991). Laboratory experiments with Synechococcus revealed a strong correlation between refractive index and intracellular carbon concentration (Stramski et al. 1995). RALS did show a general decreasing trend with increasing growth rate in our experiments (Fig. 6A), although no significant linear relationship was observed between the RALS and cellular carbon content.

In the present experiments, the C:N ratio for Synechcoccus WH7803 was high for low growth rates and approached the Redfield ratio at $0.7 \mathrm{~d}^{-1}$. For the same strain growing in nitrogen replete media under a wide range of light levels, Kana \& Glibert (1987) reported low C:N values for cells growing at low light levels and values close to the Redfield ratio for cells growing at irradiances above light saturation $\left(>160 \mu \mathrm{E} \mathrm{m}^{-2} \mathrm{~s}^{-1}\right)$. Our observed C:N ratio of 6.65 for cells growing at $0.7 \mathrm{~d}^{-1}$ agrees with their values for cells growing at $100 \mu \mathrm{E} \mathrm{m}^{-2} \mathrm{~s}^{-1}$. The high C:N ratios of slow-growing cells is presumably due to the accumulation of carbon storage products at low growth rates (Shuter 1979). The low C:N ratio of 5.07 (atom:atom) under nutrientreplete conditions ( $\mu=0.9 \mathrm{~d}^{-1}$ ) also agrees with the estimate of Verity et al. (1992) and the expected Redfield ratio for cyanobacteria (Cushing 1995). Since the Redfield ratio is associated with nutrient-saturated growth in algae, our results suggest that Synechococcus WH7803 was not nitrogen limited in this chemostat. The high nitrate concentration in the outflow medium and the low cellular C:N ratio, which matches those reported by Kana \& Glibert (1987) for cultures growing under light limitation, imply that the culture growing at $0.9 \mathrm{~d}^{-1}$ was light limited.

Kana et al. (1988) found that the cellular zeaxanthin content of Synechococcus WH7803 remained constant over a wide range of growth irradiances and that decreases in chlorophyll a at high growth irradiances were responsible for elevated zeaxanthin-to-chlorophyll a ratios. Zeaxanthin is considered to be more conservative than chlorophyll a (i.e. less variable) in response to nitrogen availability and therefore a better predictor of biomass of field populations (Gombos \& Vigh 1986, Kana et al. 1988). The present results confirmed previous findings over a range of growth rates under constant irradiance. For the growth rates examined, the carbon-to-zeaxanthin ratio was less variable than either the carbon-to-chlorophyll $a$ or the carbonto- $\beta$-carotene ratio (Fig. 7). Investigators attempting to estimate the biomass of field population using pigments as biomarkers should be aware of the variability in cellular pigment concentration and pigment-to-carbon ratios for a given species living under different nutritional conditions and at different depths in the water column. 
In conclusion, we have found that when Synechococcus strain WH7803 is grown under N-limited conditions (1) the fraction of cells in the $S$ and $G_{2}$ phases remains relatively constant, and (2) the cellular carbon, nitrogen and pigment content of this strain and their ratios vary with growth rate. These observed relationships should improve our ability to estimate Synechococcus growth rate, productivity and biomass in future field studies.

Acknowledgements. We thank Mr David Hashimoto and Ms Kristi Hanson for technical assistance. Comments from 3 anonymous reviewers improved the quality of this manuscript. This work was supported, in part, by NSF grant OCE9633091, OCE-9311246 and NASA grant NAGW-3439. Contribution 4791 from the School of Ocean and Earth Science and Technology, University of Hawaii at Manoa; and 508 from US JGOFS

\section{LITERATURE CITED}

Andersen RA, Bidigare RR, Keller MD, Latasa M (1996) A comparison of HPLC pigment signatures and electron microscopic observations for oligotrophic waters of the North Atlantic and Pacific Oceans. Deep-Sea Res II 43: $517-537$

Armbrust EV, Bowen JD, Olson RJ, Chisholm SW (1989) Effect of light on the cell cycle of a marine Synechococcus strain. Appl Environ Microbiol 55:425-432

Bannister TT (1974) Production equations in terms of chlorophyll concentration, quantum yield, and upper limit to production. Limnol Oceanogr 19:1-12

Bidigare RR, Schofield O, Prézelin BB (1989) Influence of zeaxanthin on quantum yield of photosynthesis of Synechococcus clone WH7803 (DC2). Mar Ecol Prog Ser 56: $177-188$

Binder LE, Chisholm SW (1990) Relationship between DNA cycle and growth rate in Synechococcus sp. strain PCC 6301. J Bacteriol 172:2313-2319

Binder LE, Chisholm SW (1995) Cell cycle regulation in marine Synechococcus sp. strains. Appl Environ Microbiol 61:708-717

Burkill PH, Leakey RJG, Owens NJP, Mantoura RFC \{1993\} Synechococcus and its importance to the microbial foodweb of the northwestern Indian Ocean. Deep-Sea Res II 40:773-782

Carpenter EJ, Chang J (1988) Species-specific phytoplankton growth rates via diel DNA synthesis cycles I. Concept of the method. Mar Ecol Prog Ser 32:139-148

Chisholm SW, Vaulot D, Olson RJ (1984) Cell cycle controls in phytoplankton: comparative physiology and ecology. In: Edmonds LN (ed) Cell cycle clocks. M Dekker, New York, p 365-394

Chisholm SW, Armbrust EV, Olson RJ (1986) The individual cell in phytoplankton ecology: cell cycles and flow cytometry. In: Platt T, Li WKW (eds) Photosynthetic picoplankton. Can Bull Fish Aquat Sci 214:343-369

Chisholm SW, Olson RJ, Zettler ER, Goericke R, Waterbury JB, Welschmeyer NA (1988) A novel free-living prochlorophyte abundant in the oceanic euphotic zone. Nature (Lond) 334:340-343

Chisholm SW, Frankel SL, Goericke R, Olson RJ, Palenik B,
Waterbury JB, Westjohnsrud L, Zettler ER (1992) Prochlorococcus marinus nov gen nov sp.: an oxyphytotrophic marine prokaryote containing divinyl chlorophyll $a$ and $b$. Arch Microbiol 157:297-300

Cushing DH (1995) Population production and regulation in the sea: a fisheries perspective. Cambridge University Press, Cambridge

Glover HE, Phinney DA, Yentsch CS (1985) Photosynthetic characteristics of picoplankton compared with those of larger phytoplankton populations in various water masses in the Gulf of Maine. Biol Oceanogr 3:223-248

Gombos Z, Vigh L (1986) Primary role of the cytoplasmic membrane in thermal acclimation evidenced in nitratestarved cells of the blue-green alga, Anacystis nidulans Plant Physiol 80:415-419

Johnson PW, Sieburth JM (1979) Chroococcoid cyanobacteria in the sea: a ubiquitous and diverse phototrophic biomass. Limnol Oceanogr 24:928-935

Kana TM, Glibert PM (1987) Effect of irradiances up to $2000 \mu \mathrm{E} \mathrm{m}^{-2} \mathrm{~s}^{-1}$ on marine Synechococcus WH-7803-I Growth, pigmentation, and cell composition. Deep-Sea Res 34:479-495

Kana TM, Glibert PM, Goericke R, Welschmeyer NA (1988) Zeaxanthin and $\beta$-carotene in Synechococcus WH-7803 respond differently to irradiance. Limnol Oceanogr 33: $1623-1627$

Karl D, Tupas L, Santiago-Mandujano F, Nosse C, Hebel D, Firing E, Lukas R (1996) Hawaii Ocean Time-series Program Data Report 7, 1995. SOEST Tech Report 96-9. School of Ocean and Earth Science and Technology, Univ of Hawaii, Honolulu, $\mathrm{HI}$

Laws EA, Bannister TT (1980) Nutrient- and light-limited growth of Thalassiosira fluviatilis in continuous culture, with implications for phytoplankton growth in the ocean. Limnol Oceanogr 25:457-473

Laws EA, Caperon J (1976) Carbon and nitrogen metabolism by Monochrysis lutheri: measurement of growth-ratedependent respiration rates. Mar Biol 36:85-97

Laws EA, Popp BN, Bidigare RR, Kennicutt MC, Macko SA (1995) Dependence of phytoplankton carbon isotopic composition on growth rate and $\left[\mathrm{CO}_{2}\right]_{a g}$ : theoretical considerations and experimental results. Geochim Cosmochim Acta 59:1131-1138

Laws EA, Bidigare RR, Popp BN (1997) Effect of growth rate and $\mathrm{CO}_{2}$ concentration on carbon isotopic fractionation by the marine diatom Phaeodactylum tricornutum. Limnol Oceanogr 42:1552-1560

Lee S, Fuhrman J (1987) Relationships between biovolume and biomass of naturally derived marine bacterioplankton. Appl Environ Microbiol 53:1298-1303

Liu H (1997) Estimating the growth rates of Prochlorococcus and Synechococcus in the sea from diel cell cycle analysis. $\mathrm{PhD}$ dissertation, University of Hawail at Manoa, Honolulu

Liu H, Nolla HA, Campbell L (1997) Prochlorococcus growth rate and contribution to primary production in the equatorial and subtropical North Pacific Ocean. Aquat Microbiol Ecol 12:39-47

Liu H, Campbell L, Landry MR, Nolla HA, Brown SL, Constantinou J (1998) Prochlorococcus and Synechococcus growth rates and relative contributions to production in the Arabian Sea during Southwest and Northeast Monsoons. Deep-Sea Res II 45:2327-2352

McDuff RE, Chisholm SW (1982) The calculation of in situ growth rates of phytoplankton populations from fractions of cells undergoing mitosis. Limnol Oceanogr 27 $783-788$ 
Morel A (1991) Optics of marine particles and marine optics. In: Demers S (ed) NATO ASI, G27: particle analysis in oceanography. Springer-Verlag, Berlin, p 142-188

Olson RJ, Vaulot D. Chisholm SW (1986) Effect of environmental stress on the cell cycle of two marine phytoplankton species. Plant Physiol 80:918-925

Partensky F, Blanchot J, Vaulot D (1999) Differential distribution and ecology of Prochlorococcus and Synechococcus in oceanic waters: a review. In: Charpy L, Larkum AWD (eds) Marine cyanobacteria. Bull Inst Océanogr Monaco Num Spéc 19:431-449

Rhee GY (1980) Continuous culture in phytoplankton ecology, In: Droop MR, Jannasch-HW (eds) Advances in aquatic microbiology, Vol 2. Academic Press, London, p 151-203

Shalapyonok A, Olson RJ, Shalapyonok LS (1998) Ultradian growth in Prochlorococcus spp. Appl Environ Microbiol 64:1066-1069

Shuter B (1979) A model of physiological adaptation in unicellular algae. J Theor Biol 78:519-552

Slater ML, Sharrow SO, Gart JJ (1977) Cell cycle of Saccharomyces cerevisiae in populations growing at different rates. Proc Natl Acad Sci USA 74:3850-3854

Stramski D, Shalapyonok A, Reynolds RA (1995) Optical characterization of the oceanic unicellular cyanobacterium Synechococcus grown under a day-night cycle in natural irradiance. J Geophys Res 100:13295-13307

Editorial responsibility: Otto Kinne (Editor),

Oldendorf/Luhe, Germany
Takahashi M, Kikuchi K, Hara Y (1985) Importance of picocyanobacteria biomass (unicellular, blue-green algae) in the phytoplankton population of the coastal waters off Japan. Mar Biol 89:63-69

Vaulot D, LeBot N, Marie D, Fukai E (1996) Effect of phosphorus on the Synechococcus cell cycle in surface Mediterranean waters during summer. Appl Environ Microbiol 62:2527-2533

Veldhuis MJW, Kraay GW, van Bleijswijk JDL, Baars MA (1997) Seasonal and spatial variability in phytoplankton biomass, productivity and growth in the northwestern Indian Ocean: the southwest and northeast monsoon, 1992-1993. Deep-Sea Res 44:425-449

Verity PG, Robertson CY, Tronzo CR, Andrews MG, Nelson JR, Sieracki ME (1992) Relationships between cell volume and the carbon and nitrogen content of marine photosynthetic nanoplankton. Limnol Oceanogr 37:1434-1446

Waterbury JB, Watson SW, Guillard RRL, Brand LE (1979) Widespread occurrence of a unicellular, marine, planktonic cyanobacterium. Nature (Lond) 277:293-294

Waterbury JB, Watson SW, Valois FW, Franks DG (1986) Biological and ecological characterization of the marine unicellular cyanobacteria Synechococcus. Can Bull Fish Aquat Sci 214:71-120

Weisse T (1993) Dynamics of autotrophic picoplankton in marine and freshwater ecosystems. Adv Microb Ecol 13: $327-370$

Submitted: January 19, 1999; Accepted: May 20, 1999

Proofs received from author(s): October 26, 1999 